\title{
Confronting Nuclear Tyranny: Role of Eco-nationalism in Development of Environmental Movement in Ukraine
}

\author{
Tetiana Perga \\ Institute of World History of National Academy of Science of Ukraine, Kiev, Ukraine
}

\begin{abstract}
In the USSR there has never been a "pure" environmental movement. Dictate of Moscow in decision-making led to the location of a disproportionately large number of the nuclear power stations and industrial enterprises on the territory of Ukraine. Chernobyl accident demonstrated the consequences of this approach and became the symbol of inequality of relations between the member nations in the Soviet Union. Therefore, environmentalism and nationalism in many Soviet Republics had convergence albeit to varying degrees. The purpose of this research is to contribute to the further understanding and interpretation of the concept of eco-nationalism, proposed by J. Dawson. The article demonstrates that the basis for its development in Ukrainian USSR was not only the Chernobyl accident, but also the expansion of the nuclear facilities in Ukraine (what can be considered nuclear tyranny) along with the existence of a large number of industrial enterprises that polluted the environment. The article also explores the role of nationalism in the originating the environmental movement in the republic.
\end{abstract}

Keywords: environmental movement, eco-nationalism, nationalism Ukrainian SSR, Soviet Union

\section{Introduction}

The discourse on the development of environmental activism in the Republics of the Soviet Union is often related to the nationalistic movements. This connection was certainly evident during the late Soviet Union in Ukrainian SSR where the most serious accident in the history of the nuclear industry - Chernobyl accident has occurred. American researcher J. Dawson, investigating public activism in the Soviet Union in the late 1980s substantiated this phenomenon by developing a concept of eco-nationalism. Analyzing the situation in former Soviet Republics she concluded that the anti-nuclear movement that was the most potent mobilizing issue in the environmental realm reflected popular demands for national sovereignty and regional self-determination. J. Dawson interprets eco-nationalism as the convergence of nationalism and environmentalism (Dawson, 1996). Taking into account its crucial role in the development of environmental activism, researcher focused on the case studies of four Soviet republics, where were built nuclear power plants-Russia, Ukraine, Lithuania, Armenia.

However, during recent decades the concept of eco-nationalism has neither been refuted, nor been developed. The studies on this topic provide some insights into environmental, ethnic, cultural activism in some Soviet Republics but scattered data has not generalized (Stewart, 1992; Zieger, 1992; Gorenburg, 2003; Marples, 2016). Considerable resources have been spent on studies of Ukrainian nationalism (Kuzio, 2000; 2002; Shcherbak, 2013) or environmentalism (Friendly \& Feshbach, 1992; Leukhina, 2010) without

Tetiana Perga, Ph.D., senior researcher, Institute of World History of National Academy of Science of Ukraine, Kiev, Ukraine. 
ascertainment of their connections. In result a lot of issues are to be discussed.

Without diminishing the relevance of Chernobyl accident in catalyzing dissatisfaction with the Soviet regime and mobilizing ordinary citizens who for many years were oppressed by the Soviet system, the question arises of how other Soviet nuclear projects influenced on the development of eco-nationalism. What is the connection between the ambitious nuclear plans of the Soviet leadership and the emergence of the anti-nuclear movement? What was the degree of maintenance the intensity of environmental movement by nationalism? Why in some cases anti-nuclear activism merged with the nationalist movement, and in others developed separately, only using some of its slogans?

This paper will analyze the role of the USSR's plans to increase production of nuclear power in the Ukrainian SSR in the development of eco-nationalism in the late 1980s. Focus will be on the level of penetration of the nationalistic demands on the Ukrainian environmental movement. It will be argued that the scale of the nuclear penetration of the Soviet Union in Ukraine provided, from one side, consolidation of society on the platform of eco-nationalism, from the other side, development of environmental movement in its own way.

\section{Role of the Nuclear Energy in the Development of the Soviet Union}

Nuclear energy played important role in the development of the USSR. There were some reasons for this. Industrialization of the country which started in late 1920s and continued in the 1950s resulted in implementation of many large-scale construction projects (researchers even use the term "gigantomania") that demanded electricity. In 1956, the Soviet physicist and one of the main figures in the Soviet nuclear program, "the father of the Soviet atomic bomb" Igor Kurchatov stated that despite Soviet Union was not threatened with a shortage of raw materials, the cheap hydro resources will be exhausted in long-term perspective, and the extraction and transportation of long-range fossil fuels will be costly. He considered that the rapidly growing industry and agriculture will require a significant increase in the production of electric and thermal energy (Kurchatov, 1956). However, in the Soviet Union was a disproportion between the location of the main energy resources and the most inhabited territories which population consumed electricity. About 80 percent of energy resources were concentrated on the eastern regions of the country, while 75 percent of the population and consumers of power lived in the European part of the USSR. The transportation of fuel from the east of the Soviet Union to the western regions constituted about $40 \%$ of the turnover of the country's rail freight which from an economic perspective was unprofitable (Zholudev \& Konstantinov, 1978). Therefore, Kurchatov considered that in the future nuclear energy may turn out to be virtually inexhaustible and a relatively cheap source that will provide enough energy in the European part of the USSR.

Use of nuclear energy opened up new prospects not only for the saving of valuable hydrocarbons (oil and gas), but also for the development of the technological processes of new quality—ones that can take place at a temperature of $1000{ }^{\circ} \mathrm{C}$ (in 1960-1970s it was possible to produce only heat of low and medium potential—at temperature of 200-300 ${ }^{\circ} \mathrm{C}$ ). Their implementation had to contribute to the increasing of the competitiveness of the Soviet planned economy. In this context, the leaders of the Soviet Union bet on promotion of the Soviet science by popularizing the achievements of the nuclear power.

It should be taken into account that Soviet scientists substantiated the development of nuclear energy by environmental arguments. Although the USSR denied the existence of ecological problems, Soviet scientists developed technologies to reduce the harmful emissions. They were considering the possibility of creating a new 
type of "clean" public transport that could use hydrogen as fuels generated by the nuclear energy and combustible products. As Dr. A. M. Petrosyants, Chairman of the USSR State Committee on the Utilization of Atomic Energy stated in 1979 at the Atomic Industrial Forum in Washington

the nuclear power development and the analysis of its future prospects... is equally important in the solving ... of preservation of human environment. In our country this is considered as the problem of the highest priority. Recently, in September (1972), special legislation on the protection of the environment was approved by the Supreme Soviet of the USSR. We feel that the broad nuclear power development allows us to kill two rabbits with one shot. It gives abundant electricity to the population and decreases the pollution of the environment. (Petrosyants, 1980, p. 7)

However, the strengthening of economic potential of the Soviet Union, in particular through the development of nuclear energy, served not only the pragmatic interests. It fulfilled ideological function and was seen as a means to challenge the superior position of the West and the United States. Technological utopianism was idealized as one of the highest forms of culture. This demonstrates high level of politicization of the nuclear science and technology in the USSR.

The first nuclear power projects were started in the Soviet Union even before the end of the 1940s. In 1950 the decision was taken to construct the country's first nuclear power plant at Obninsk, based on the so-called channel-type, uranium-graphite design of reactor. The world's first nuclear power plant was commissioned on 27 June 1954. It opened a new era in the history of the Soviet Union - the era of the nuclear power. From the very beginning, the Soviet propaganda have accented on the peaceful use of the nuclear energy on the contrary to the arms race. This tone was set by the first official statement published in the newspaper Pravda on July 1, 1954, noted that "...introduction of the nuclear energy has made a real step towards the peaceful use of the nuclear energy" (Pravda, 1954, p. 1).

The energy strategy of the USSR provided the gradual increase in the production of nuclear energy that actualized after the world energy crisis of 1970s. In 1981, the 26th Congress of the Communist Party of the Soviet Union (CPSU) decided that almost all growth of electricity production in the European part of the country should be achieved by the construction of nuclear power and hydro electrical plants (Semenov, 1983). In 1981, the Soviet Union's nuclear power plants generated 86 billion kWh electricity- $6.5 \%$ of the country's total electricity production. It was planned that during the next five-year period the generation figure would increase more than threefold and reach 220 billion $\mathrm{kWh}$ in 1985 (14\% of the total electricity production in the entire country and $24 \%$ in the European region) (Semenov, 1983).

These plans of the Soviet leadership were directly related to Ukrainian SSR which was the industrial core of the Soviet Union and where located many industrial facilities and enterprises of military-industrial complex. Besides, after Leonid Brezhnev rose to power in the Communist Party of the USSR in the second half of 1970s investments in the economy of Ukraine have significantly dropped. This led to the stagnation in the development of the coal industry which was the main source of energy in the Republic. Dr. David Marples considered stagnation in Donbass coalfield an important reason for the widespread development of nuclear energy in the Ukrainian SSR, as a replacement for fossil fuels (Marples, 1987).

Another reason for Ukraine's choice as the place for the location of nuclear power plants was its neighborhood with the countries of the socialist block. As is known, the Soviet Union supported the economy of the satellite countries, including the supply of cheap electricity. Of the four Ukrainian nuclear plants operating in 1985, two were exporting electricity to Romania, Bulgaria, Poland, and Hungary, while a third (Khmelnytsky) also for East European needs was scheduled to come on-line in 1986 (Marples, 1987). It was also expected that 
by the end of the 20th century the nuclear power plants of the socialist countries will produce up to $45 \%$ of the total electricity (Zholudev \& Konstantinov, 1987).

According to the ambitious plans of the Soviet leadership, between 1977 and 1989, 16 nuclear power reactors total capacity of 14,800 MWe were to built in five nuclear power plants in Ukraine-Chernobyl, South-Ukrainian, Khmelnytsky, Rivne, Zaporozhye (Kuchma, 1997). In the mid-1980s, the idea of building two additional facilities - nuclear power station in the Crimea and Chyhyryn also appeared. In Armenia it was built one reactor, the same in Lithuania.

These factors testify the significant Soviet nuclear expansion of Moscow in Ukraine. It was particularly dangerous for two reasons. First of all, it was lack of a safety culture in the Soviet Union. Due to the extraordinary secrecy that surrounded the Soviet nuclear industry, scientists were unable to take advantage of relevant technologies developed in the Western countries or to use the experience of the 1979 Three Mile Island accident in the United States. This applied both to the exploitation of the nuclear power plants and to the awareness of local population on the danger of the radioactive pollution. Since in the USSR the practice of public discussions on issues relating to the life of local population was absent, Soviet citizens believed the assurances of the leadership in the safety of the peaceful atom. In result many people both the liquidators and the population of the surrounding territories received high doses of radiation after the explosion of Chernobyl reactor (UNSCEAR, 2012).

\section{Emergence of Anti-nuclear Activism in the Ukrainian SSR}

Despite increasing the role of nuclear energy in the total electricity supply in the Soviet Union in 1970-1980s, anti-nuclear activism (in this essay it is understood as a social movement that opposes various nuclear facilities) was not reinvigorated. In the USSR, environmental policy was highly ideologized. On the official Soviet view, ecological problems were simply one of the measures of the crisis of capitalism. Thereafter, Soviet policies were, by definition, environmentally sound. Environmental waste, abuse, and mismanagement, according to the public statements of the leadership, simply could not exist in the USSR. Nature protection activism of citizens was put under the control of the state. Members of informal movement of youth associations called Nature Protection Brigades (dryzinnoje dvizenije), mainly liberal-minded intellectuals and young people who sought the possibility to serve society outside state structures were engaged mainly in the fight with poaching. As a result of political isolation and the Cold War, the Soviet citizens were not able to get any information about environmental or anti-nuclear activism in the West; accident at Three Mile Island nuclear plant was hidden. Therefore, nuclear power was not accepted as possible threat to the health and life of people. Moreover, due to the privileged position of the workers of nuclear industry many citizens sought the possibility to get the work at nuclear power plants. Before the Chernobyl accident, the citizens of the USSR (and the Ukrainian SSR) unconditionally believed the government and its assurances in the safety of the "peaceful" atom and its progressive role; most of them were loyal to the regime.

Chernobyl accident represented a fundamental shift in the relationship between the Soviet citizenry and the state. All of a sudden the USSR witnessed a new phenomenon - the grassroots, green movement. In Ukraine and Belarus that were most affected by Chernobyl, as well as in republics where operated nuclear power plants, these movements were gaining strength at an unprecedented pace. There is no doubt that Chernobyl accident attracted attention not only to the nuclear power plants, but also to a wide range of local environmental problems. However nuclear theme became the central in the Ukrainian environmental movement 
of late 1980s. This can be explained by the fact that due to lack of access to reliable information, Chernobyl spawned many rumors and fears; many Ukrainians felt abandoned by the representatives of the Soviet party elite, who cared only about their families. Hence, slogans of suspending construction of new nuclear reactors reflected aspirations of the most of the Ukrainians.

Nevertheless, as a result of slowing down the processes of perestroika in Ukrainian SSR anti-nuclear activism was slow to emerge in the republic. While in Lithuania it reached peak in summer of 1988, the most active stage of Ukrainian movement started only in 1989-1990. The main attention was focused on the construction of the Chyhyryn, Rivne, Khmelnytskyi, Southern Ukraine, and Crimean Nuclear Power Plants. Some of these projects, such as the Chyhyryn and the Crimean nuclear power stations, were objectively dangerous. For example, according to the project, Chyhyryn Nuclear Power Plant was supposed to be in a densely populated region on the banks of Kremenchug water reservoir that was a part of the republic's main water supply Dniper River. Crimean nuclear power station was planned to place in a high seismic activity zone on the seaside of the Black Sea, which considered a resort of all-union importance.

Distrusting the Soviet government, which discredited itself in the case of the Chernobyl accident, citizens demanded suspend the construction of these facilities. Except of petitioning, publications in the newspaper Literaturna Ukraina, and the local Crimean press (Krimskij Komsomolec, Krimskaja Pravda) (Andronyaky, 1989a; 1989b; Syhanova, 1988; Svidzinsky, 1990) there were many spontaneous rallies and protests in different Ukrainian settlements. For example, in 1987-1989, the environmental group Ecology and Peace gathered 350,000 signatures against the construction of the Crimean Nuclear Power Station (EALM, 1987).

Particular resentment among the leaders of anti-nuclear activism caused plans of the Soviet leaders to build an additional 6,000 megawatts of electrical capacity at stations in the republic. Activists insisted that the maximum productive capacity of Ukrainian nuclear power plants should not exceed four thousand megawatts. This idea has manifested in an appeal to the nineteenth All-Union Conference of the Soviet Communist Party, held in June 1988. In the document, titled "Concerning a Review of the Program for the Development of Nuclear Energy in Ukraine" activists demanded to freeze construction of all existed nuclear power plants and justify this from a scientific point of view (Solchanyk, 1988).

The above facts testify the very deep expansion of the Soviet nuclear industry in Ukraine, which is possible to characterize as nuclear tyranny. We regard tyranny as the unlimited use of power by the Soviet Communist elites; nuclear tyranny is viewed as the implementation of ambitious program on dramatic increasing of nuclear energy production without any control or limits, without taking into account the environmental consequences for the Soviet Republics. Despite Ukraine occupied approximately 3.7 percent of the territory of the USSR it had to produce forty percent of the electricity generated at the Soviet nuclear power plants. Before the Chernobyl accident, no one understood the scale of this penetration and potential threat. However gradually national consciousness of the population of Soviet Ukraine was born. Chernobyl revealed itself not only as a technological catastrophe, but also as the symptom of failing system. An important role in this played the policy of perestroika and glasnost, which was conducted by the first secretary of the CPSU Mikhail Gorbachev.

\section{Role of Nationalism in the Development of the Environmental Movement in Ukraine}

In the late 1980s, besides the ecological activism, the national movement began to develop in Ukraine. In the scientific discourse of last decades it is often connected with ethnic nationalism (Gorenburg, 2001; 2003; 
Guiliano, 2011). In the context of this research we regard it as advocacy of or support for the interests of a particular ethnic group, especially with regard to its national independence or self-determination. After Chernobyl accident, the main reason for its emergence in the Ukrainian USSR was the discrepancy between the rights of nations and ethnic groups declared in the Soviet Constitutions and the real situation. The USSR pursued a policy of Russification aimed to impose Russian language, ideals, and beliefs on non-Russian communities, restricted using of languages of titular groups in education, culture, work of local authorities, as well as creating and work of ethnic institutions.

Chernobyl accelerated general discontent with the Soviet totalitarian regime, particularly dictate of Moscow in the cultural and ethnic policy. This manifested in the founding of a large number of informal groups that paid attention to the development on Ukrainian language and culture. Most of the 47,000 informal groups (clubs, political and cultural associations) that existed in Ukraine in 1986 were engaged in these activities (TSDAVO of Ukraine, 1989).

The peculiarity of the ecological movement that originated in Ukraine in the late 1980s is a close connection with nationalism, particularly the movement for the expansion of cultural and political rights, which soon transformed into a movement for the gaining the independence from the Soviet Union. Nationalistic slogans have become quite strong mobilizing by force (although to a lesser extent than in the Baltic Republics). It happened because in the result of Chernobyl accident the nuclear threat could be easily transformed into the symbol of the dominance of one ethnic group (Russians) over another (Ukrainians), between the central Soviet authorities and the republic. Concern for national territory coincided with concern for the environment. This idea was understood by all groups of Ukrainian society—both intellectuals and ordinary people.

Already in 1987-1988, the first informal groups emerged in the Ukrainian SSR-the Ukrainian Cultural Club, the Ukrainian Helsinki Union, the Leon Society, the Community, the Heritage. The archival documents of the KGB and the Central Committee of the Communist Party of Ukraine demonstrate that these and many other informal groups along with questions of the Ukrainian language and culture raised questions on the closure of nuclear power plants and the provision of reliable information about their impact on the environment and people's health. Very often, protests and rallies began with the slogans of using the Ukrainian symbols and language; creation of the Ukrainian church; increasing the number of Ukrainian schools; and finished with appeals to close nuclear power plants and harmful enterprises. On the other hand, many environmental protests and rallies discussed issues of citizen participation in decision-making, expansion of rights of ethnic minorities, Ukraine's sovereignty (EALM, 1988; TSDAVO of Ukraine, 1989). These demands became intertwined and complementary.

Important role in the initiating of the environmental activism in Ukraine played the group most susceptible to nationalist ideas - the intelligentsia. In Ukrainian realities these were not scientists but writers who since 1987, actively promoted the idea of national revival of Ukraine. Ukrainian writers took the lead in voicing anxiety about the threat of nuclear power. Many of them were very impressed by the Chernobyl tragedy which some glorified before the accident. Therefore, they felt a moral obligation to contribute in the improvement of the situation.

Union of Writers of Ukraine founded the Environmental Commission, which started environmental workshops. They were conducted by writer Sergii Plachinda, who later became the first Chairmen of the association "Green World". During 1988-1989, writers published a series of publications, devoted to the 
closure of Chyhyryn and Crimea nuclear power stations and suspension of construction of new blocks at the Rivne and Khmelnytskyi Nuclear Power stations.

In the fall of 1987, after the conference on the environmental consequences of Chernobyl accident, writers and some activists decided to create an environmental association "Green World". It was registered under the umbrella of the Ukrainian branch of the Soviet Peace Committee leaded by the famous Ukrainian writer Oles Honchar. He provided essential assistance to the work of "Green World": association received office, meeting room, an address for correspondence, telecommunication equipment and funding for business trips in the regions (Samoilenko, 2017). In result of this it soon transformed in the largest umbrella environmental civil organization in Ukraine. Many local environmental groups declared themselves the members of the association.

Memoirs of the members of "Green World" and KGB documents allow to conclude that during the meetings of the association in the Union of Writers of Ukraine was born the idea of creating a "People's Front" (RUKH) which later became the most popular nationalistic movement in the Republic. It was officially announced by writers Sergii Plachinda, Ivan Drach, and Dmytro Pavlychko (members of "Green World") during the first sanctioned by authorities rally on ecology, held in Kyiv on November 13, 1988 (EALM, 1988). When RUKH was created, some members of the "Green World" joined it. Those who stayed in association, worked closely with RUKH, participated in all its activities. There was even the idea of turning the "Green World" into an environmental fraction of RUKH (Samoilenko, 2017).

As the Chairman of the association, writer Yurii Shcherbak, who was elected by the constituent assembly in 1989, noted, unlike grass-roots environmental initiatives, which put the ecological problems at the forefront, majority of members of the "Green World" association were "eco-patriots", who considered the most important the development of the Ukrainian State (Samoilenko, 2017). They viewed the achievement of state sovereignty as the main condition for solving environmental problems in Ukraine. Writers involved in the environmental movements many scientists who prepared an evidence base for many requirements.

It is possible to agree with the statement of J. Dawson that in Ukraine environmental and nationalist movements developed in parallel, convergences, but not replaced each other (as it was in Lithuanian SSR and Armenian SSR). Thus, the environmental movement developed as an independent direction of the protest movement although its goals (protection of water, land, life of local ethnic groups, closing the dangers industrial or nuclear facilities) had natural affinity with the purposes of nationalism. It benefited substantially from the mobilization potential of national identity. However, it did not transform into a movement for the national liberation and did not dissolve into it. Using arguments of some researchers (Kuzio, 2002; Dawson, 1996), this feature can be explained with the weakness of Ukrainian nationalism in the period under study in result of the lack of elites, regional divisions, and fear of loss of territorial integrity (Kuzio, 2000).

This paper presents the idea that one more reason for this was the Soviet nuclear tyranny of Ukraine. The number and scale of the nuclear projects that were implemented in Ukraine in the 1980s, as well as a large number of industrial enterprises that polluted the environment, required long-term and wide-scale efforts of the citizens as well as the involvement of experts - scientists and specialists in nuclear energy, chemical industry, biology, ecology. Only while Nikita Khrushchev was chairman of the Council of Ministers of the Ukrainian SSR, 35 new industrial facilities and 250 large chemical enterprises were built in the republic. In 1990, Ukraine produced $44.5 \%$ of iron ore, $40.8 \%$ of pig iron, $34.5 \%$ of rolled ferrous metals, $34.1 \%$ of steel of the total produced in the USSR (Statistical Yearbook, 1990). Such high level of industrialization of Ukraine led to the emergence of a number of environmental problems. Some researchers even characterize this policy of the 
USSR towards republic as an ecocide (Friendly \& Feshbach, 1992), understanding such its consequences as the destruction of large areas of the natural environment by such activity as nuclear warfare, overexploitation of resources, or dumping of harmful chemicals. Ukraine covered about 3.7 percent of the former Soviet Union's territory but produced almost 25 percent of all industrial pollution (Vasiyta, 1998). Thus the scale of the problems and tasks provided the basis for the concentration of environmental activism on the "pure" environmentalism which prevented its merger with the movement for national independence.

\section{Conclusions}

Thus, the basis for the development of eco-nationalism in the Ukrainian SSR should be considered not only the Chernobyl accident, but also the nuclear tyranny of the Soviet Union towards the republic. Nationalism played important role in the initial stage of environmental movement in Ukrainian SSR because the achievement of the sovereignty of the republic was considered as a pledge to solve environmental problems and close the nuclear power plants. However national-sovereignty and environmental movements developed separately and did not convergence. This can be explained not only by the weakness of the national identity, but also by large-scale tasks of Ukrainian environmental movement because the economic policy of the USSR led Ukraine into a deep ecological crisis.

\section{References}

About the launch in the USSR of the first industrial electric station on the nuclear energy. (1954). Pravda, 82, 1.

Andronyaky, V. (1989a). Crimea-In the red book?” Krimskij Komsomolec, $20,5$.

Andronyaky, V. (1989b). Crimea-In the red book? Act! Krimskij Komsomolec, 22, 4.

Andronyaky, V. (1989). Time does not wait. Krimskij Komsomolec, 25, 5.

Announcement of the KGB to the Central Committee "About Meetings, Paces, and Prayers in the Crimean, Lviv, Ivano-Frankivsk Region" and "About the Situation in the Mines of Chervonograd". (September 25, 1986). Electronic archive of the liberation movement (hereafter-EALM). Retrieved October 7, 2018, from http://avr.org.ua/index.php/viewDoc/11248/

Communication of the KGB USSR to the CCCPSU dated 14.11.1988. (1988). About the meeting on the problems of ecology which took place in Kiev. EALM. Retrieved October 7, 2018, from http://avr.org.ua/index.php/viewDoc/11231/

Dawson, J. (1996). Eco-nationalism: Anti-nuclear activism and national identity in Russia, Lithuania, and Ukraine. Durham, NC: Duke University Press.

Friendly, M., \& Feshbach, A. (1992). Ecocide in the USSR: The looming disaster in soviet health and environment. New York: Basic Books.

Gorenburg, D. (2001). Nationalism for masses: Popular support for nationalism in Russia's ethnic republics. Europe-Asia Studies, 53(1), 73-104.

Gorenburg, D. (2003). Minority ethnic mobilization in the Russian federation. Cambridge: Cambridge University Press.

Guiliano, E. (2011). Constructing grievances. Ethnic nationalism in Russia's Republics. Ithaca and London: Cornell University Press.

Information message of the KGB of the Ukrainian SSR to the Central Committee of the CPSU dated 14.11.1988. (1988). On the meeting on the problems of ecology which took place in Kiev. EALM. Retrieved October 7, 2018, from http://avr.org.ua/index.php/viewDoc/11231/

Kurchatov, I. (1956). Some issues of the development of nuclear energy in the USSR. Nuclear Energy, 3, 5-9.

Kuzio, T. (2000). Nationalism in Ukraine: Towards a new framework. Politics, 20(2), 77-86.

Kuzio, T. (2002). Nationalism in Ukraine: Towards a new theoretical and comparative framework. Journal of Political Ideologies, $7(2), 133-161$.

Kuchma, L. D. (1997). Statement by Ukrainian president L. D. Kuchma at the nineteenth special session of the UN General Assembly. To ensure the environmental safety of the planet. Governmental Courier,_26, 1-7, 3.

Leukhina, A. (2010). Ukrainian environmental NGOs after Chernobyl catastrophe: Trends and issues. International Journal of Politics and Good Governance, 17(1), 1-12. 
Letter to Secretary of the Central Committee of the Communist Party of Ukraine Kachura B.V. from the Head of the Social-Economic Department of the Central Committee of the Communist Party of Ukraine A. Svchenko No. 889/109 of May 3, 1989. (1989). About the Republican Conference of the Association "Green World”. Central State Archives of the Supreme Bodies of Power and Government of Україне (hereafter-TSDAVO of Ukraine). Fond 32, Part 1, Deal 32, File 2611.

Letter of the Secretary of Mykolaiv Regional Committee of the Communist Party of Ukraine to Shcherbytskyi V. V. No. 85 dated 04.19.1989. (1989). TSDAVO of Ukraine. Fond 32, Part 1, Deal 32, File 2611.

Marples, D. (1987). Chernobyl and nuclear power in the USSR. Badsingstoke: Palgrave Macmillan.

Marples, D. (2016). The collapse of the Soviet Union, 1985-1991. Abingdon: Routledge.

Note of Department 5 of the KGB, "About Some Active Amateur Civil Organizations of Kiev", November 15, 1988. (1988). EALM. Retrieved October 7, 2018, from http://avr.org.ua/index.php/viewDoc/11238/

On the work of party committees of the republic with amateur public organizations. (June 24, 1989). TSDAVO of Ukraine, F1, D32, File 2658.

Petrosyants A. Nuclear Power Development in the USSR. From a speech delivered at the Atomic Industrial Forum in Washington $\begin{array}{llllll}\text { last } \quad \text { (1980). } & \text { Revember. } & \text { October } & 5, & \text { 2018, } & \text { from }\end{array}$ https://www.iaea.org/sites/default/files/publications/magazines/bulletin/bull15-3/15304790209.pdf

Semenov, B. (1983) Nuclear power in the Soviet Union. IAEA Bulletin, 25(2), 47-59.

Shcherbak, A. (2013). Nationalism in the USSR: A historical and comparative perspective. Basic research program working papers series: Sociology WP BRP 27/SOC/201. Retrieved October 5, 2018, from https://wp.hse.ru/data/2013/12/12/1339827667/27SOC2013.pdf

Solchanyk, R. (1988). Ukrainians appeal to party conference about development of nuclear energy. Ukrainian Weekly, $28,15$.

Samoilenko, Y. (2017). Green wave of independence. Ukrainian Environmental Association "Green World”. Kyiv: Publishing House "Green Patriot".

Statistical Yearbook. (1990). National economy of the USSR in 1990. Moscow: Finance and Statistics Publishing House.

Stewart, J. (1992). The Soviet environment: Problems, policies, and politics. Cambridge: Cambridge University Press.

Syhanova, S. (1988). Resort and NPP are incompatible. Krimskaja Pravda, 120, 3.

Svidzinsky, A. (1990). Moral aspects of nuclear energy. Literaturna Ukraina, 17, 1.

UNSCEAR. (2012). UNSCEAR's assessments of the radiation effects of the Chernobyl accident. Retrieved October 1, 2018, from http://www.unscear.org/unscear/en/chernobyl.html

Vasiyta, O. (1998). Ecology and politics. Chernivtsi: Zelena Bukovina.

Zholudev, I., \& Konstantinov, L. (1978). Nuclear power energy in the USSR. IAEA Bulletin Атомная, 22(2), 34-46.

Zieger, C. (1992). Political participation, nationalism, and environmental politics in the USSR. In J. M. Stewart (Ed.), The Soviet environment: Problems, policies, and politics (pp. 24-39). Cambridge: Cambridge University Press. 